\title{
RISIKO TINGKAT SUKU BUNGA DI PASAR KEUANGAN TURKI PADA PERIODE WAKTU YANG BERBEDA
}

\author{
Durmuş Özdemir ${ }^{1}$ \\ Harald Schmidbauer $^{2}$
}

\begin{abstract}
A Measuring the risk associated with interest rates is important since it is beneficial in taking measures before negative effects can take place in an economy. We obtain a risk measure for interest rates by fitting the generalized Pareto distribution (GPD) to positive extreme day-to-day changes of the interest rate, using data from the Istanbul Stock Exchange (ISE) Second Hand Bond Market, namely Government Bond interest rate closing quotations, for the time period 2001 through 2009. Although the use of the GPD in the context of absolute interest rates is well documented in literature, our approach is different insofar and contributes to the literature as changes in interest rates constitute the target of our analysis, reflecting the idea that risk arises from abrupt changes in interest rate rather than in interest rate levels themselves. Our study clearly shows that the GPD, when applied to interest rate changes, provides a good tool for interest rate risk assessment, and permit a period-specific risk evaluation.
\end{abstract}

Keyword: Interest rate risk; covered interest parity; Turkey; generalized Pareto distribution

\author{
JEL Classification: G1; C1
}

1 Corresponding author: Istanbul Bilgi University, Department of Economics, Dolapdere Campus, Kurtuluș, Deresi Cad., Yahya Köprüsü Sok.No: 1, 34440 Beyoğlu, Istanbul, Turkey, Tel.+902123115326, Fax+902122970134, E-mail: dozdemir@bilgi.edu.tr.

2 Department of Business Administration, Bilgi University, Santral Campus, Eski Silahtarağa Elektrik Santrali, Kazım Karabekir Cad. No: 2/13, 34060 Eyup, Istanbul, Turkey, Tel.+902123117789, E-mail: harald@hs-stat.com. 


\section{PENDAHULUAN}

Risiko menggambarkan adanya kemungkinan terjadinya fenomena yang tidak diinginkan dan sesuatu yang non-accrual dan tidak terduga dan/atau direncanakan. Dalam ekonomi, risiko adalah kemungkinan terjadinya kerugian moneter akibat adanya transaksi dan kerugian yang diakibatkan menurunnya imbal hasil keuangan. Fluktuasi yang bersifat siklus dan perubahan harga dapat meningkatkan terjadinya risiko yang tidak diinginkan.

Risiko dibagi menjadi dua, yaitu risiko yang bersifat sistemik dan sistematis. Seluruh instrumen sekuritas pada pasar modal termasuk ke dalam risiko yang sistematis, di mana risiko ini terjadi akibat adanya fluktuasi atau ketidakpastian politik dan ekonomi yang selanjutnya memberikan pengaruh kepada perilaku aset dalam pasar modal. Sehingga, risiko sistematik dalam pasar modal adalah sesuatu yang tidak dapat dihindari atau tidak mungkin untuk dikendalikan. Di sisi lain, risiko sistemik adalah risiko yang berkaitan dengan rangkaian proses yang dikendalikan/dijalankan seperti risiko investasi di dalam sebuah perusahaan yang dapat terjadi akibat, misalnya, sebuah keputusan yang berkenaan dengan aspek keuangan (Turanlı, Özden and Demirhan (2002))

Risiko tingkat suku bunga yang terjadi merupakan bagian dari risiko yang sistematis. Fluktuasi tingkat suku bunga tidak dapat sepenuhnya dikendalikan, namun pengukuran dengan metode tertentu dapat dilakukan untuk mengatasi risiko suku bunga ini.

Pengukuran risiko tingkat suku bunga sangat penting karena berguna untuk mengukur seberapa besar dampak negatif dari sebuah kejadian yang tidak diinginkan dalam perekonomian (lihat Woodford, 1999). Dalam kajian keuangan, suku bunga seharusnya tidak hanya dilihat dalam konteks ekonomi saja, namun juga dalam konteks lain. Menurut Ang dan Bekaert (2002), risiko yang ada dibalik suku bunga memberikan dampak langsung pada proses dan mekanisme pasar. Duffie dan Kan (1996) serta Dai dan Singleton (2002) menunjukkan bahwa tingkat suku bunga tidak hanya memberikan dampak pada bekerjanya pasar, namun juga mampu untuk mengubah struktur pasar tersebut.

Di sisi lain, terdapat begitu banyak sudut pandang mengenai hal ini. Sudut pandang financial income menyebutkan bahwa pendapatan yang akan dihasilkan di masa depan, dipengaruhi oleh tingkat suku bunga dikarenakan perhitungan nilai saat ini dilakukan dengan memasukkan asumsi tingkat suku bunga. Jika ada perubahan yang tidak terduga pada suku bunga, maka terjadi risiko yang membuat nilai pendapatan menjadi lebih rendah dibandingkan yang sebelumnya diperkirakan.

Di sisi lain, sudut pandang institutional menyebutkan bahwa perubahan tingkat suku bunga berpengaruh pada nilai pasar suatu institusi keuangan (Carneiro dan Sherris, 2008). Hal ini dikarenakan nilai dari aset dan kewajiban institusi keuangan di satu sisi dan off-balancesheet contracts (tercermin pada suku bunga) di sisi lain, dipengaruhi oleh perubahan tingkat suku bunga dan nilai sekarang dari arus kas masa depan; bahkan dalam beberapa kasus, arus kas masa depan ini sendiri dapat mengalami perubahan. 
Fokus utama dari penelitian ini adalah untuk mengukur risiko tingkat suku bunga pada pasar spot obligasi pemerintah di Turki. Pertama-tama, kami mengamati apa yang telah terjadi pada ekonomi Turki selama periode 2001 hingga 2009. Kemudian kami mengamati perubahan tingkat suku bunga harian secara statistik.

Paper ini menganalisis tail index dengan menggunakan the Generalized Pareto Distribution (GPD). Konsep ini kemudian diterapkan pada data runtun waktu suku bunga dan melihat kondisi ketika perubahan suku bunga melebihi suatu threshold tertentu. Tail index dapat membantu untuk melihat apakah suatu ditribusi data memiliki heavy tails. Pendekatan yang sama (namun diterapkan pada suku bunga itu sendiri, bukan pada perubahannya) digunakan oleh Bali dan Neftchi (2001) untuk menghitung Value at Risk (VaR) suku bunga pada pasar Amerika. Meyfredi (2005) menggunakan estimasi pengukuran risiko yang berhubungan dengan fat tails pada imbal hasil pasar saham pada beberapa negara. Perilaku joint threshold exceedances dari imbal hasil saham internasional diamati oleh Schmidbauer dan Rösch (2004). Mereka menunjukkan bagaimana GPD bivariate berguna dalam menilai risiko keuangan antar pasar pada periode bull dan bear.

Gencay, Selçuk dan Ulugulyağcı (2002) menggunakan metode ini untuk data yang bersumber dari Istanbul Stock Exchange, dan menghasilkan VaR yang dapat digunakan sebagai early warning system untuk pasar. Gencay dan Selcuk (2001) menggunakan metodologi yang sama untuk tingkat suku bunga overnight pada pasar uang Turki untuk melihat apakah suku bunga overnight (ex-ante) merupakan indikator krisis 2001 atau bukan.

Bagian kedua dari paper ini mengulas tinjauan literatur dan teori yang berhubungan dengan suku bunga. Bagian ketiga membahas data dan metodologi yang digunakan, sementara bagian keempat menyajikan hasil pengolahan data dan analisisnya. Kesimpulan dan saran disajikan pada bagian teakhir dan menjadi penutup paper ini.

\section{TEORI}

Banyak faktor yang dapat menentukan bentuk distribusi tingkat suku banga. Perilaku mikro, fenomena makro secara agregat, dan faktor eksternal termasuk gejolak negatif dapat merubah dinamika suku bunga; baik secara bertahap ataupun berubah secara drastis. Dari sudut pandang internasional, hukum covered interestrate parity dapat memberian gambaran hubungan mendasar antara variabel suku bunga, nilai tukar, dan inflasi.

Dinamika umum suku bunga telah diketahui sejak lama, salah satu contohnya adalah volatilitas suku bunga bersifat yang stochastic. Hal ini juga jelas bahwa suku bunga cenderung memiliki volatilitas yang terkluster, khususnya saat bergerak dari volatilitas rendah menjadi tinggi; lihat Andersen dan Lund (1997) pada Allan Sall Tang Adersen (2011).

Borodin dan Strokov (2011) mengamati hubungan antara suku bunga dan perdagangan internasional antar negara-negara BRIC, dan menemukan bahwa negara dengan tingkat suku 
bunga rendah mengalami pertumbuhan proporsi ekspor produk industri mesin dibandingkan pertanian dan produk makanan, begitupun sebaliknya. Di sisi lain, pada negara yang memiliki tingkat suku bunga yang tinggi, proporsi ekspor produk pertanian dan makanan meningkat dan proporsi ekspor produk mesin menurun. Pengamatan ini telah menunjukkan bahwa perubahan relatif pada suku bunga berpengaruh terhadap spesialisasi yang terjadi pada negara-negara tersebut.

David Andolfatto (2012) menggunakan model neoklasik sederhana dan menemukan bahwa guncangan likuiditas dalam dan luar negeri berpotensi mengakibatkan terjadinya ketidakseimbangan perdagangan dan menurunkan tingkat suku bunga, yang dianggap sejalan dengan hipotesis global saving glut yang dikemukakan oleh Bernanke.

Tuner (2014) menemukan bahwa banyak negara maju termasuk FED, Bank of Japan, dan Bank of England membeli obligasi pemerntah dalam jumlah besar untuk menurunkan tingkat suku bunga dalam jangka panjang, dan untuk menstimulus permintaan secara agregat. Hal ini menunjukkan bahwa suku bunga jangka panjang kini telah menjadi target antara (intermediate target) yang penting bagi bank sentral di beberapa ekonomi negara maju, yang juga memberikan pengaruh terhadap suku bunga jangka pendek. Hubungan antara nilai tukar, suku bunga jangka pendek, dan suku bunga jangka panjang dapat dilihat pada gambar di bawah ini:

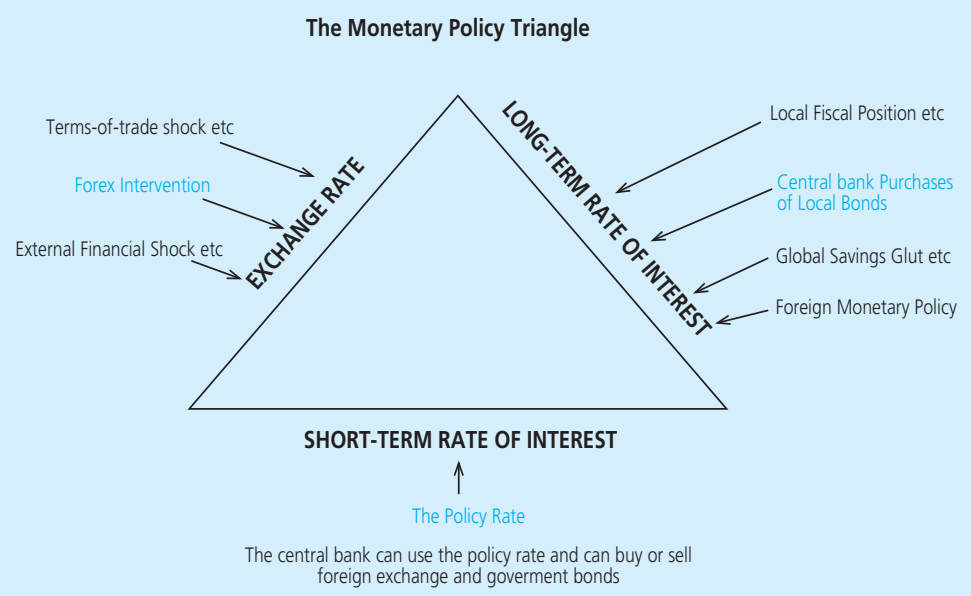

Spesifikasi yang lebih formal diberikan oleh Conway dan Orr (2002) yang menyusun sebuah model tingkat suku bunga global (Global Interest Rate Model/GIRM) berdasarkan konsep pasar obligasi yang efisien, di mana banyak peluang arbitrase yang dimanfaatkan oleh investor global. Model ini mengidentifikasi tiga kategori penentu dinamika suku bunga, fundamental 
ekonomi, perbedaan yield obligasi jangka pendek dari yield jangka panjangnya, dan integrasi pasar keuangan global.

Desroches dan Francis (2007) menemukan perilaku suku bunga riil dunia yang dipengaruhi oleh sejumlah variabel kunci yang relatif berubah secara perlahan sepanjang waktu. Mereka juga menggunakan pertumbuhan tenaga kerja, yang mempengaruhi tingkat investasi, dan struktur usia pada ekonomi dunia, yang mempengaruhi simpanan, dan juga tingkat perkembangan keuangan.

Baru-baru ini, Abbritti, Salvatore, Moreno, dan Sola (2013) menggunakan model FAVAR untuk memodelkan global term structure. Dengan menggunakan data panel atas kurva yield internasional, mereka menjelaskan bahwa faktor global berperan besar yakni lebih dari $80 \%$ atas premi (term premia) pada ekonomi maju, dan faktor domestik lebih relevan untuk menjelaskan dinamika suku bunga jangka pendek.

Faktor-faktor yang telah dijelaskan di atas akan menentukan bentuk distribusi dari suku bunga, yang kemungkinan besar akan memiliki fat tail. Fisher dan Tippett (1928) pertama kali memperkenalkan metode tradisional dalam memodelkan data dengan nilai ekstrim (extremevalue data); metode ini didasarkan pada extreme-value limiting distribution. Pickands (1975) memperkenalkan Generalized Pareto Distribution (GPD) sebagai kelas distribusi dengan dua parameter atau dikenal dengan exceedances over threshold. Penelitian selanjutnya mengembangkan teori tersebut sebagaimana dilakukan oleh Hosking dan Wallis (2001), Gencay dan Selcuk (2004), Gencay, Selcuk, dan Ulugulyağcı (2002), Schmidbauer dan Rösch (2004) dan Meyfredi (2005).

Carr dan Wu (2007) menjelaskan bahwa currency options memiliki kecondongan distribusi (skewness) yang berubah-ubah seiring waktu (time-varying skewness). Dengan menggunakan model-free estimates atas volatilitas dan kecondongan suku bunga, mereka menemukan bahwa distribusi suku bunga juga bersifat time-varying skewness (lihat Trolled dan Schwartz (2010)). Tujuan utama dari penelitian tersebut adalah untuk menyajikan kerangka yang konsisten untuk pemodelan volatility dan skewness yang bersifat stokastik. Lebih dari itu, kalibrasi model dengan data pasar menjadi menarik karena dapat menunjukkan manfaat model tersebut.

\section{METODOLOGI}

\subsection{Generalized Pareto Distribution (GPD)}

Jika $i_{t}$ adalah tingkat suku bunga harian ( $t$ mengindikasikan harian), maka perubahan hariannya dapat secara matematis dijelaskan sebagai berikut:

$$
r_{t}=\frac{i_{t}-i_{t-1}}{i_{t-1}} \cdot 100 \%
$$


Fokus utama dari penelitian ini adalah untuk mengkaji perilaku upper threshold exceedance dari series sebagai dasar dari Generalized Pareto Distribution (GPD), yang merupakan model untuk excesses random variable. Dasar penggunaan GPD adalah limit theorem yang menyatakan bahwa ${ }^{3}$ jika $r_{1}, \ldots r_{n}$ adalah variabel random yang terdistribusi secara idiosentris dan identik (iid), dan jika $R$ terdistribusi seperti $r_{i^{\prime}}$ maka untuk $n$ dan $u$ dalam jumlah besar, maka terdapat $\xi$ dan $\sigma$ sedemikian rupa sehingga terdapat distribusi yang merupakan fungsi dari excess $(r-u)$ dan kondisional terhadap $R>u$. Bentuk fungsi distribusi ini dapat diperoleh dari:

$$
\mathrm{F}(\mathrm{x} ; \xi, \sigma)=\left\{\begin{array}{cc}
1-\left(1+\xi \frac{\mathrm{x}}{\sigma}\right)^{-1 / \xi} & ; \text { if } \xi \neq 0 \\
1-\exp \left(-\frac{\mathrm{x}}{\sigma}\right) & ; \text { if } \xi=0
\end{array}\right\}
$$

Pada formula tersebut, $\sigma>0$ adalah parameter skala, hal ini bergantung pada threshold dan probability density function $r_{i}$. Parameter yang kedua adalah shape parameter $\xi$, dan dikenal sebagai tail index. Shape parameter ini disebut tail index karena menentukan karakteristik bentuk ekor dari suatu fungsi densitas yakni sebagai berikut:

- Jika $\xi>0$, maka fungsi distribusi akan memiliki distribusi dengan ekor yang tebal (fat-tailed distributions), dan dalam hal ini GPD tidak akan bersifat general lagi sehingga menjadi pareto distribution.

- Jika $\xi=0$, maka fungsi distribusi akan memiliki ekor yang tipis (thin-tailed distributions); dalam hal ini GPD akan berubah menjadi distribusi eksponensial dengan rata-rata $\sigma$.

- Jika $\xi<0$, maka fungsi distribusi tidak akan memiliki ekor (misalnya finite distributions).

- $\quad$ Saat $\xi=1$, maka GPD akan menjadi uniform distribution pada interval $[0, \sigma]$.

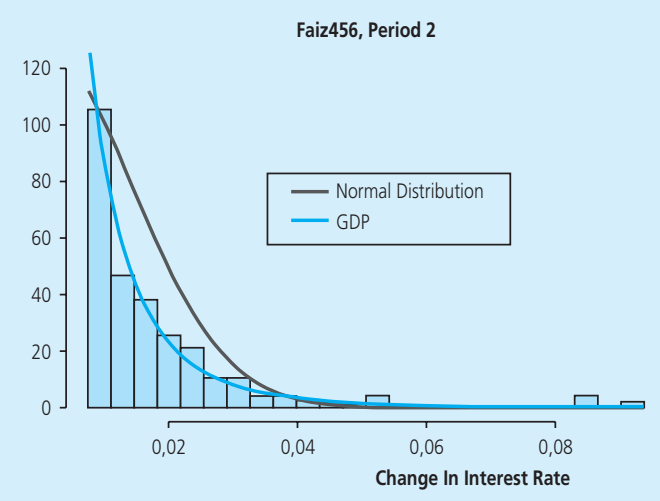

Grafik 1. Kalibrasi GPD dan Data

3 Contohnya, lihat Coles (2001). 
Contoh khusus dari aplikasi GPD atas upper tail dari salah satu variabel $\left(r_{-} t\right)$ ditunjukkan pada Grafik 1. Histogram tersebut menunjukkan distribusi empiris upper tail rangkaian perubahan tingkat suku bunga harian (faiz 456, yakni suku bunga penutupan harian untuk obligasi pemerintah yang telah jatuh tempo, yang diperdagangkan di ISE Bounded Bind Purchasing Market selama periode kedua), di mana kami menggunakan kwantil 80\% sebagai titik potongnya. Kwantil ini digunakan sebagai titik potong pada keseluruhan penelitian ini. Garis merah adalah densitas dari distribusi normal dengan rata-rata dan varians yang sama dengan faiz 456 pada periode kedua, dan garis hijau adalah densitas GPD yang dikalibrasikan ke data. Grafik tersebut menunjukkan dengan jelas bahwa distribusi normal over-estimates untuk probabilitas perubahan yang moderat namun under-estimates untuk probabilitas perubahan yang besar. Ini menegaskan bahwa penggunaan distribusi normal tidak sesuai untuk menganalisis variabel risiko seperti yang dikaji dalam paper ini.

Secara teknis, perhitungan dilakukan dengan menggunakan paket "evd" (lihat Stephenson, 2002) yang terdapat pada perangkat lunak statistik $R$ (Tim Inti $R$, 2013) untuk melakukan kalibrasi GPD pada data. Teknik estimasi yang digunakan pada "evd" adalah maximum likelihood. Standard error di uji silang dengan menggunakaan bootstrap untuk memastikan tingkat keakurasiannya.

\subsection{Data}

Kami menggunakan data penutupan suku bunga harian yaitu 90, 182, 273, dan 456 hari terhadap jatuh tempo obligasi pemerintah yang diperdagangkan pada ISE Bounded Bond Purchasing Market. Periode analisis kami mencakup Januari 2001 hingga Desember 2009. Data diakses dari ISE.

Sebelum menerapkan metode GPD, langkah pertama adalah mengindentifikasi ada tidaknya structural break di sepanjang periode observasi. Investigasi yang dilakukan mencakup empat periode. Plotdat nya disajikan pada pada Grafik 2 untuk keempat periode investigasi tersebut. Dalam pasar keuangan Turki, tidak terdapat obligasi perusahaan. Pasar hutang Turki didominasi oleh Treasury Bonds.

\section{HASIL DAN ANALISIS}

\subsection{Structural Breaks pada Data Suku Bunga}

Langkah pertama yang dilakukan adalah membagi periode observasi menjadi sub-periode dengan menggunakan structural break test untuk data runtun waktu suku bunga harian. Bagian ini juga akan menyajikan argumentasi lebih jauh mengenai analisis risiko yang terpisah pada tiga sub-periode. ${ }^{4}$ Selain itu bagian ini akan menunjukkan keterbatasan model regresi tersebut saat digunakan pada time series suku bunga.

4 Kami menganalisis periode Januari 2001 hingga Agustus 2008, sesuai hasil pengujian structural breaks. Periode selanjutnya turut disertakan (yaitu Periode 4) dengan alasan pertimbangan analisis ekonomi. 
Metode yang kami gunakan dapat mengidentifikasi breakpoints pada hubungan regresi dengan suku bunga sebagai variabel terkiat dependent dan waktu (misalnya harian) sebagai variabel bebas independent. Metode ini berdasarkan Bai dan Peron (2003); dan telah diterapkan oleh Zeileis, Kleiber, Kramer, dan Hornik (2003). Breakpoints dihitung dengan tujuan untuk meminimalisir jumlah kuadrat kesalahan (residual sum of squares) dengan kendala bahwa tidak boleh ada segmen periode yang lebih pendek dari 15 persen dari total panjang periode yang digunakan. (Kami menggunakan data runtun waktu dimulai dari Januari 2001 hingga Agustus 2008 adalah 1930 hari). Jumlah breakpoints tidak ditentukan di awal, melainkan secara endogen dapat diperoleh dari prosedur optimisasi ini.

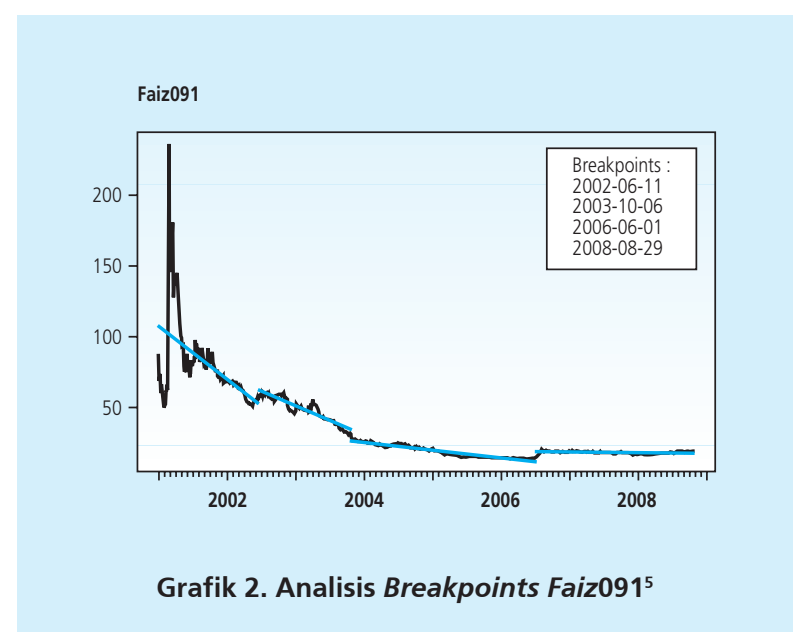

Uji perubahan strukural berhasil mengidentifikasi empat buah breakpoints pada series faiz091. Series ini dipilih untuk menunjukkan evolusi pergerakan tingkat suku bunga, dan hasil dari analisis breakpoints tersebut disajikan pada Grafik 3.

Pada analisis selanjutnya, kami mengabaikan breakpoint pertama dan membentuk periode 1 dan mengambil tanggal 2003-10-06 sebagai titik waktu terakhir.Hal ini dibenarkan karena relatif terdapat homogenitas dalam selang periode ini. Dengan demikian, maka periodisasi yang dipilih mengacu pada sub-periode dengan karakteristik masing-masing sebagaimana disajikan pada Tabel 1.

5 Faiz091 adalah penutupan suku bunga harian selama 90 hari jatuh tempo pada obligasi pemerintah yang diperdagangkan pada ISE Bounded Bond Purchasing Market . 


\subsection{Karakterisasi masing-masing Sub-Periode}

Keseluruhan periode observasi dapat dibagi kedalam dua sub periode utama; hingga periode 2002, dan periode dari 2003 hingga 2009. Pada awal peridoe 2001 hingga akhir 2002 terdapat tiga kejadian yang membentuk periode ini: krisis ekonomi terjadi pada 28 Februari 2001, 11 September 2011, dan Pemilihan Umum Turki pada 2002. Periode tersebut diwarnai oleh dengan banyak ketidakstabilan terkait kondisi ekonomi dan politik.

\begin{tabular}{l|c|c|c|c} 
& \multicolumn{2}{|c}{ Pembagian periode Januari 2001 - Desember 2009 menjadi sub-periode } \\
\hline Periode & Mulai & Berakhir & \multicolumn{1}{c}{ Karakteristik } \\
\hline Periode 1 & $2001-01-02$ & $2003-10-06$ & $\begin{array}{l}\text { Suku bunga tinggi, menurun tajam setelah mencapai } \\
\text { titik tertingginya; fluktuasi harian yang sangat besar }\end{array}$ \\
\hline Periode 2 & $2003-10-07$ & $2006-06-01$ & $\begin{array}{l}\text { Suku bunga yang lebih moderat, menurun; fluktuasi } \\
\text { harian yang kecil }\end{array}$ \\
\hline Periode 3 & $2006-06-02$ & $2008-08-29$ & $\begin{array}{l}\text { Suku bunga yang moderat pada tingkatan yang relatif } \\
\text { stabil; fluktuasi harian yang cukup moderat }\end{array}$ \\
\hline Periode 4 & $2008-09-01$ & $2009-12-31$ & $\begin{array}{l}\text { Sama dengan periode 3, namun dengan "potensi } \\
\text { kejutan" yang lebih tinggi dikarenakan kurtosis yang } \\
\text { lebih tinggi. }\end{array}$ \\
\hline
\end{tabular}

Selama periode waktu antara 2003 dan 2008, pertumbuhan ekonomi Turki tercatat rata-rata sebesar 7\%. Produk Domestik Bruto (PDB) per kapita meningkat sebesar 30\%, dan mata uang Lira megalami revaluasi sebesar 30 persen. Di sisi lain, 100 persen kemunduran terjadi pada defisit perdagangan dan neraca pembayaran Turki. Inflasi menurun hingga 12\% dari sebelumnya $40 \%$, serta suku bunga menurun hingga $21 \%$ dari sebelumnya $76 \%$ pada akhir $2001^{6}$.

\section{Periode antara Januari 2001 dan September 2003}

Seperti telah dijelaskan di atas, apa yang terjadi pada periode tersebut disebabkan oleh ketidakstabilan ekonomi dan politik. Sebuah resolusi di bawah wewenang Turkish National Assembly untuk mengirim pasukan ke Irak telah disetujui dengan suara lebih dari 50 persen

6 Seluruh gambar dikases dari: Laporan Pasar Keuangan Banking Regulation and Supervision Agency (BDDK), Maret - Juni 2006, Nomor1-2. Tersedia secara online di http://www.bddk.org.tr/english/Reports/Financial Markets Report/1971fprMart Haziran2006ingilizce.pdf. Diakses pada Oktober 2008. 
pada 16 Oktober 2003. Pemberitaan media sehari setelahnya menyebutkan pasar memandang hal ini sebagai perwujudan dari "integritas politik"7.

Hal ini juga penting untuk diketahui bahwa inflasi pada bulan Oktober 2003 merupakan inflasi terendah selama 30 tahun terakhir ${ }^{8}$. Sehari setelahnya, kementerian keuangan pemerintah mengumumkan kebijakan restrukturisasi hutang dalam bentuk mengganti obligasi pemerintah berjangka pendek dengan obligasi berjangka lebih panjang. Suku bunga menurun sebesar 200 basis poin, dan Pemerintah Turki kemudian dapat melakukan pinjaman jangka panjang. ${ }^{9}$

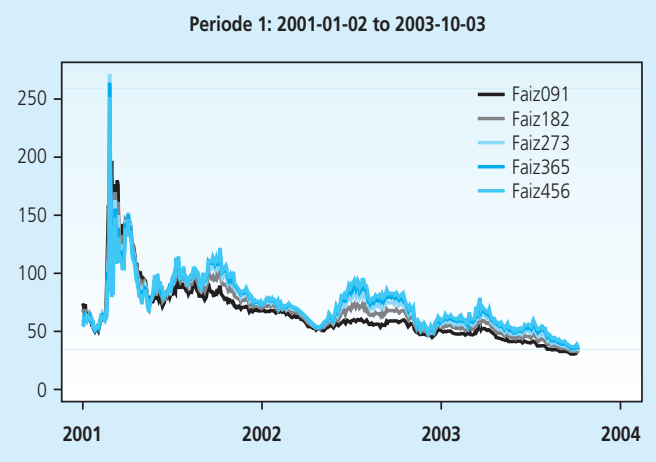

Grafik 3. The Faiz Series, Periode 1

\section{Periode antara Oktober dan Mei 2006}

Terdapat empat kejadian pada tahun 2003 yang membentuk periode tersebut: WTO menghilangkan hambatan perdagangan, liberalisasi arus pergerakan modal, pertumbuhan ekonomi maju yang semakin meningkat, dan peningkatan inflasi pada negara-negara maju.

Dalam periode ini, pergerakan modal lintas pasar sangat tinggi. Total volume sirkulasi modal di seluruh dunia dalam periode ini mencapai USD15 Triliun berdasarkan IMF Economic Outlook ${ }^{10}$. Dalam konteks ini, negara-negara berkembang juga memberikan kontribusi. Sejumlah USD2 triliun dari total aliran modal sebesar USD15 triliun tersebut, mengalir dari negara-negara berkembang. Proporsi investasi asing di Turki mencapai USD90 miliar, berdasarkan Turkish Central Bank Inflation Report ${ }^{11}$.

7 Hurriyet Online: "Tezkere Geçti Asker Iraka Gidiyor, Kabul 358 Red 183", date: 2003-10-07. Tersedia secara online di at http:// webarsiv.hurriyet.com.tr/2003/10/07/hurriyetim.asp. Diakses pada Oktober 2008.

8 Hurriyet Online: "Enflasyona Eylül Çelmesi", date: 2003-10-04. Tersedia secara online di http://webarsiv.hurriyet.com.tr/2003/10/03/ hurriyetim.asp. Diakses pada Oktober 2008.

9 Hurriyet Online: "Para Kurulu Toplandı", Tanggal: 2003-10-15. Tersedia secara online di http://webarsiv.hurriyet.com.tr/2003/10/15/ hurriyetim.asp. Diakses Oktober 2008.

10 International Monetary Fund (IMF) World Economic Outlook, Oktober 2006, pp. 1-6. Tersedia secara online di http://www.imf.org/ external/pubind.htm.Diakses pada Oktober 2008.

11 Turkish Central Bank, Infation Report 2006-IV, pp. 41-46. Tersedia secara online di http://www.tcmb.gov.tr/.Diakses pada Oktober 2008. 


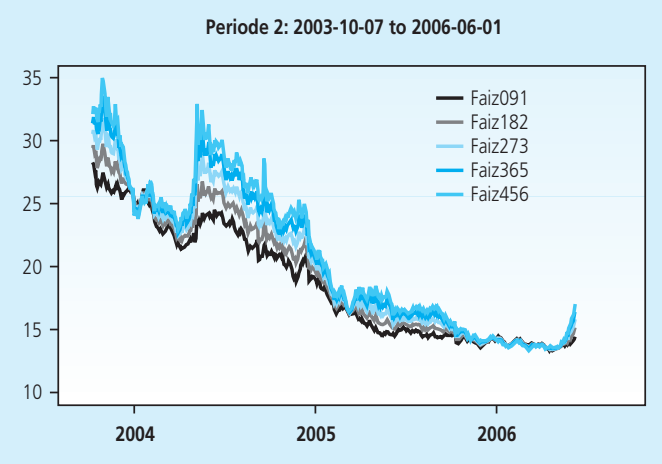

Grafik 4. The Faiz Series, Periode 2

\section{Periode antara 02-06-2006 dan 29-08-2008}

Terdapat empat kejadian utama yang membentuk periode ${ }^{12}$ ini. Karakteristik pertama dalam periode ini pertama adalah inflasi yang mengancam negara-negara maju; kedua, peningkatan tingkat suku bunga; ketiga, krisis sub-prime yang terjadi pada tahun 2007; dan keempat, krisis perbankan di seluruh dunia.

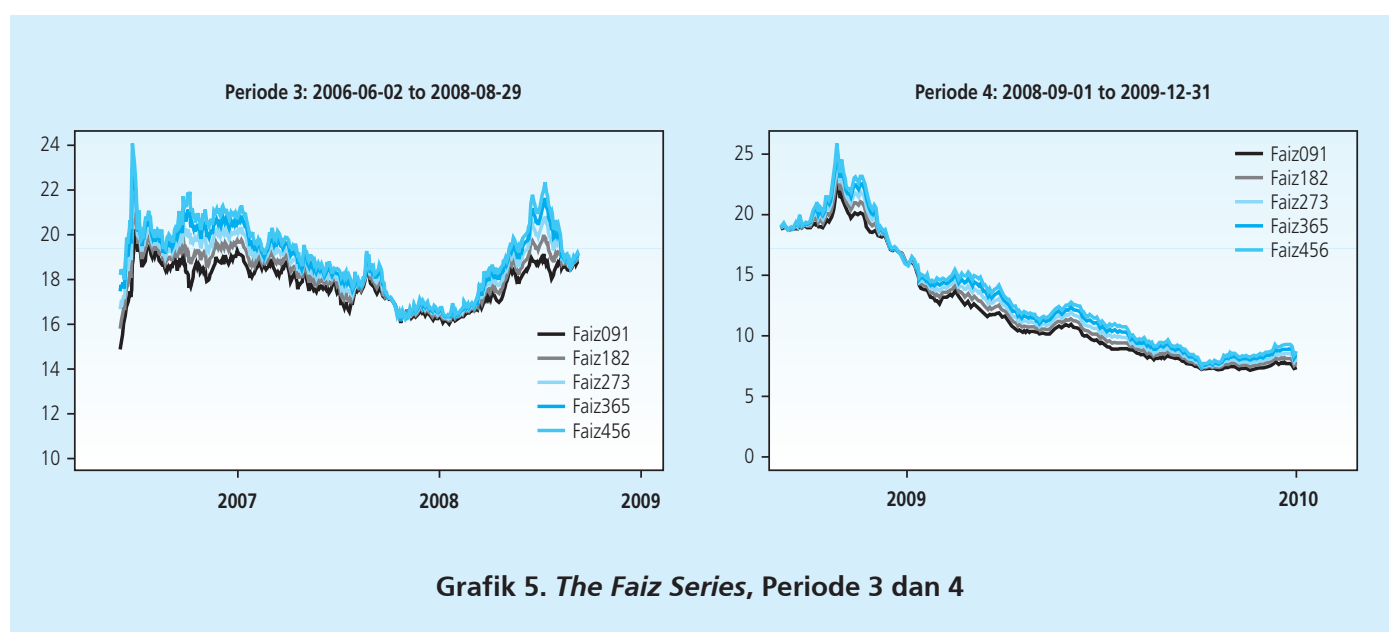

12 International Monetary Fund (IMF) World Economic Outlook, Oktober 2008: Financial Stress, Downturns and Recoveries, pp. 1-46. Tersedia secara online di http://www.imf.org/external/pubs/ft/weo/2008/02/pdf/text.pdf. Diakses pada Oktober 2008. 


\subsection{Analisis Statistik Perubahan Suku Bunga Harian}

Tabel 4 dan 5 pada lampiran di bawah menjelaskan karakteristik distribusi atas persentase perubahan kelima data untuk keempat periode. Ini mencakup rata-ata, varians dan standar deviasi, kecondongan (skewness), kurtosis, niliai minimum, nilai tengah, dan nilai maksimum. Tujuan dari penelitian ini merupakan evaluasi risiko suku bunga. Maka dari itu, dua hal terpenting dari besaran statistik ini adalah pembahasan tentang variance dan kurtosis.

Terdapat perbedaan yang sangat mencolok antar keempat periode tersebut. Cakupan perubahan harian yang paling besar terjadi pada periode 1; varians dan kurtosis terbesar juga terjadi pada periode 1 ini. Perilaku kelima series dalam masing-masing periode ini dapat menunjukkan perbedaan variasi maturitas dalam periode yang bersangkutan, tapi selain itu juga dapat mengungkapkan lebih jauh perbedaan lintas periode. Secara mendetail, beberapa karakteristik yang terdapat pada tabel 4 dan 5 adalah:

- Rata-rata hitung perubahan harian pada yang meningkat dari faiz091 menjadi faiz456 sebagian besar terjadi pada periode 1. Hal ini nampaknya disebabkan oleh periode 1 lebih berisiko bagi para investor dikarenakan risk premium pasar modal Turki masih tinggi. Ini menyebabkan investor meminta suku bunga tinggi untuk jatuh tempo yang lebih panjang sebagai kompensasi dari risiko yang mungkin terjadi di masa depan.

- $\quad$ Varians meningkat dari faiz091 menjadi faiz456 pada seluruh periode. Dengan kata lain risiko suku bunga meningkat seiring dengan periode jatuh tempo.

- Perilaku distribusi tail lebih kompleks sebagaimana tercermin dari besaran kurtosis. Kurtosis yang membesar dikarenakan peningkatan jatuh tempo hanya terjadi pada periode 1. Hal ini lagi-lagi untuk mengantisipasi risiko yang terjadi akibat jatuh tempo yang lebih panjang pada periode 1. Hasil pada Tabel 4 dan Tabel 5 menunjukkan tingginya risiko pada periode 1, risiko pada periode 2 dan 3 lebih rendah (dan sama), dan cenderung lebih tinggi pada periode 4 (meski dengan "potensi kejutan" yang lebih rendah, sebagaimana ditunjukkan oleh kurtosis yang lebih kecil).

Kurtosis tersebut pada umumnya menunjukkan heavy tails pada semua periode di seluruh series, dengan beberapa pengecualian. Semakin Kompleks kurtosis, maka akan semakin besar justifikasi untuk menggunakan GPD dalam menganalisis perilaku tail distribusi perubahan suku bunga.

- Rasio antara perubahan persentase minimum dan maksimum mengalami peningkatan sejalan dengan jatuh tempo pada periode 1, 2, 3; sementara untuk periode 4 justru menurun. Hal ini juga dapat dilihat dengan jelas pada boxplots Gambar 4.

- Pada periode 1, titik waktu terjadinya minimum dan maksimum selalu sama, atau sangat berdekatan. 


\subsection{Pengukuran Risiko Tingkat Suku Bunga Berdasarkan GPD}

Hasil estimasi ditunjukkan pada Tabel 2. Pada konteks pengukuran risiko yang diangkat dalam paper ini, hasil estimasi parameter tail index $\xi^{\wedge}$ lebih penting dibandingkan parameter $\sigma^{\wedge}$. Sebagaimana dijelaskan sebelumnya, tail index yang positif mengindikasikan bahwa distribusi perubahan suku bunga memiliki heavy upper tail (lihat Tabel 2).

- Estimasi parameter $\xi$ dan $\sigma$ GPD, bersamaan dengan standard error nya, berdasarkan perubahan suku bunga harian (dihitung dengan $r_{t}=\ln \left(i_{t}-i_{t-1}\right)$ ) berada di atas kwantil empiris 80\% (berdasarkan threshold exceedances sebesar kwantil 80\%) untuk setiap periode.

- $\quad$ 95\% dan 99\% kwantil perubahan suku bunga (masing-masing pada kolom q dan )

- Masing-masing besaran kwantil ini diperoleh dengan menambahkan GPD-based quantile terhadap 80\% kwantil empiris (yang berfungsi sebagai threshold).

Kesamaan yang relatif dekat antara pasangan terakhir lintas seluruh periode yang diamati dan lintas jatuh tempo suku bunga dapat diartikan sebagai konfirmasi atas akuratnya model.

Masing-masing perbedaan lintas keempat periode atas bentuk dan karakteristik distribution tail perubahan suku bunga dapat dijelaskan sebagai berikut:

- Periode 1 memiliki nilai $\xi$ yang tinggi untuk setiap data suku bunga yang diamati: Kelima tail indices bernilai positif dan signifikan dengan tingkat signifikansi 5\%. Ini mengindikasikan data memiliki bentuk distribusi dengan ekor tebal (heavy tails distribution), yang berarti terdapat peningkatan risiko suku bunga keesokan hari akan lebih tinggi dibandingkan suku bunga hari ini.

- Pengamatan terhadap tail index sejauh ini menunjukkan bahwa terdapat sedikit perbedaan antara periode 2 dan 3. Dalam periode ini, tidak satupun distribusi perubahan suku bunga memiliki bentuk heavy-tailed, dengan pengecualian faiz456. Hal ini menunjukkan bahwa peningkatan suku bunga overnight hanya terjadi pada obligasi ber jangka panjang.

- Kondisi khusus atas bentuk distribusi pada faiz456 hilang pada Periode 4.

- Distribusi normal tidak cocok untuk mengukur risiko yang berhubungan dengan tingkat suku bunga di Turki. Pada sisi lain, pemodelan eksplisit bentuk distribusi dengan aplikasi Generalized Pareto Distribution (GPD) terbukti sangat sesuai dan memberikan tingkat akurasi yang tinggi antara risiko (VaRs) teoritis dengan kwantil empirisnya.

\subsection{Pembahasan}

Pada bagian ini, kami akan mencoba untuk menggambarkan implikasi ekonomi penelitian ini untuk menjelaskan kesesuaiannya dengan argumentasi ekonomi. Kami mengkaji risiko suku bunga pada ekonomi Turki, dan dalam hal ini pemodelan statistik dapat menjadi kunci untuk mengembangkan skor risiko tersebut.Terdapat banyak alasan ekonomi terkait perbedaan tingkat 
risiko pada suku bunga. Skor risiko secara statistik dapat memberikan kontribusi yang berguna untuk pengambilan keputusan dalam kondisi ketidakpastian yang tinggi. Asumsi umum dari sebuah pengambilan keputusan bergantung pada terjadinya suatu kondisi (advese event), dan kami memiliki data yang mengindikasikan bagaimana kecenderungan atas suatu kejadian ini bergantung pada nilai dari faktor risiko yang dapat diamati.
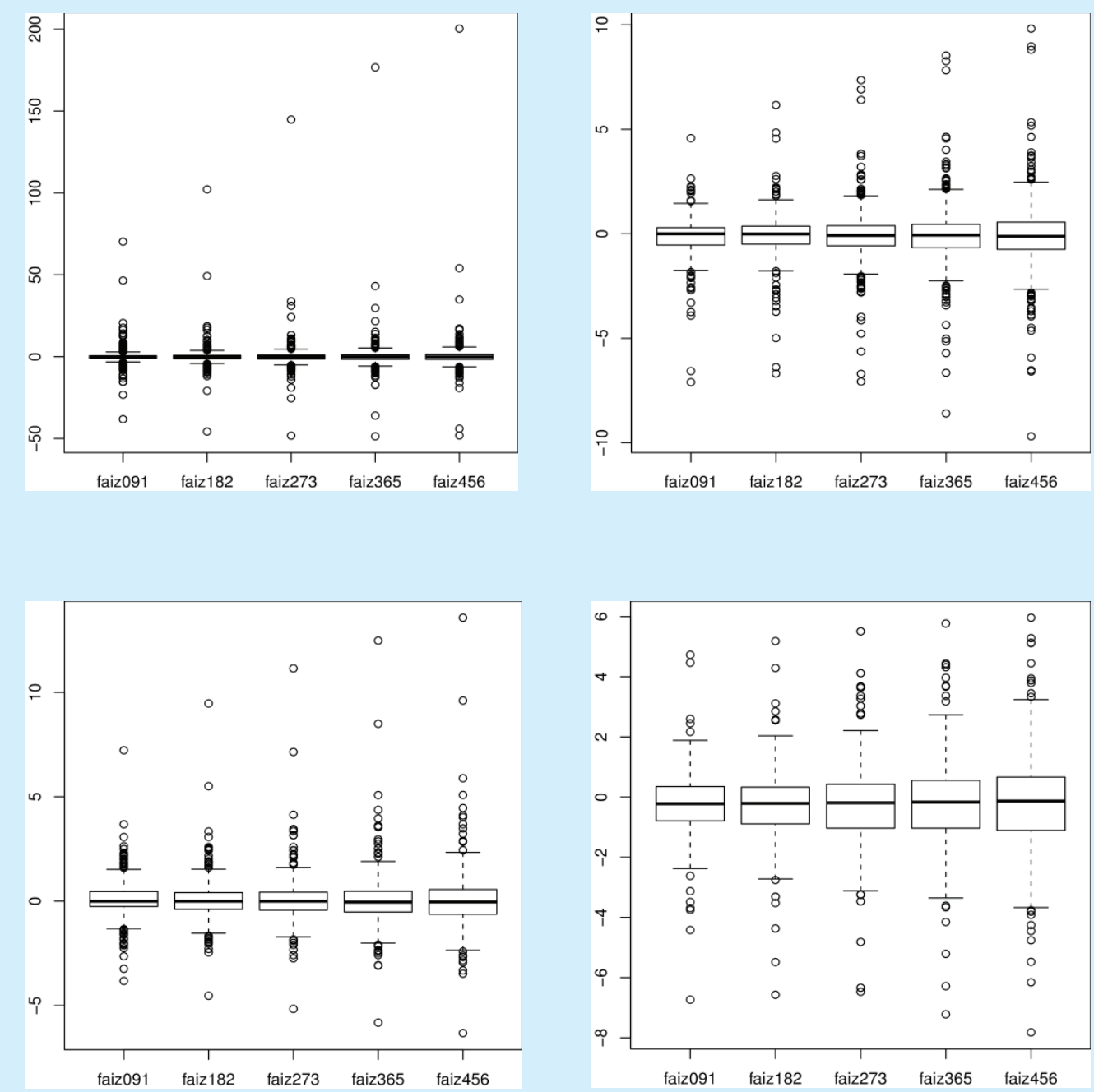

Grafik 6. Boxplots Perubahan Suku Bunga, Empat Periode 
Indikator risiko dapat dijelaskan dengan mengkaji nilai ekstrim suku bunga dalam kerangka teori nilai yang ekstrim. Teori ini merupakan kerangka yang sangat berguna untuk mempelajari bentuk ekor suatu distribusi; sehingga hal ini dapat menjadi indikator yang baik untuk risiko.

\begin{tabular}{|c|c|c|c|c|c|c|c|c|}
\hline \multicolumn{9}{|c|}{$\begin{array}{c}\text { Tabel } 2 \\
\text { Parameter GPD yang disesuaikan }\end{array}$} \\
\hline \multicolumn{3}{|c|}{${ }^{`} \xi$ std.err. ${ }^{`} \xi$} & 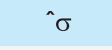 & \multicolumn{2}{|c|}{ std.err. ^ $\sigma$} & q. $955 \%$ VaR & \multicolumn{2}{|c|}{ q.99 1\% VaR } \\
\hline \multicolumn{9}{|c|}{ periode 1: 2001-01-02 - 2003-10-06 (692 observasi) } \\
\hline faiz091 & 0,6213 & 0,1404 & 0,0120 & 0,0018 & 0,0347 & 0,0346 & 0,1185 & 0,1133 \\
\hline faiz182 & 0,5195 & 0,1283 & 0,0143 & 0,0021 & 0,0404 & 0,0402 & 0,0988 & 0,1141 \\
\hline faiz273 & 0,4886 & 0,1265 & 0,0168 & 0,0024 & 0,0520 & 0,0474 & 0,1028 & 0,1283 \\
\hline faiz365 & 0,4155 & 0,1156 & 0,0211 & 0,0029 & 0,0569 & 0,0553 & 0,1044 & 0,1412 \\
\hline faiz456 & 0,3993 & 0,1131 & 0,0236 & 0,0032 & 0,0614 & 0,0607 & 0,1144 & 0,1532 \\
\hline \multicolumn{9}{|c|}{ periode 2: 2003-10-07 - 2006-06-01 (666 observasi) } \\
\hline faiz091 & 0,0000 & 0,0565 & 0,0047 & 0,0005 & 0,0101 & 0,0107 & 0,0197 & 0,0184 \\
\hline faiz182 & 0,0000 & 0,0469 & 0,0062 & 0,0007 & 0,0119 & 0,0127 & 0,0213 & 0,0227 \\
\hline faiz273 & 0,0000 & 0,0444 & 0,0077 & 0,0009 & 0,0151 & 0,0157 & 0,0278 & 0,0281 \\
\hline faiz365 & 0,0000 & 0,0449 & 0,0091 & 0,0011 & 0,0183 & 0,0189 & 0,0332 & 0,0336 \\
\hline faiz456 & 0,2796 & 0,1129 & 0,0073 & 0,0010 & 0,0214 & 0,0201 & 0,0373 & 0,0419 \\
\hline \multicolumn{9}{|c|}{ periode 3: 2006-06-02 - 2008-08-29 (569 observasi) } \\
\hline faiz091 & 0,0000 & 0,0480 & 0,0065 & 0,0007 & 0,0126 & 0,0141 & 0,0224 & 0,0246 \\
\hline faiz182 & 0,0000 & 0,0325 & 0,0067 & 0,0007 & 0,0120 & 0,0144 & 0,0251 & 0,0252 \\
\hline faiz273 & 0,0000 & 0,0311 & 0,0077 & 0,0009 & 0,0136 & 0,0160 & 0,0317 & 0,0284 \\
\hline faiz365 & 0,2990 & 0,1044 & 0,0058 & 0,0008 & 0,0155 & 0,0164 & 0,0353 & 0,0347 \\
\hline faiz456 & 0,3056 & 0,1068 & 0,0065 & 0,0009 & 0,0166 & 0,0184 & 0,0396 & 0,0389 \\
\hline \multicolumn{9}{|c|}{ periode 4: 2008-09-01 - 2009-12-31 (332 observasi) } \\
\hline faiz091 & 0,0000 & 0,0687 & 0,0057 & 0,0009 & 0,0108 & 0,0123 & 0,0232 & 0,0215 \\
\hline faiz182 & 0,0000 & 0,0843 & 0,0067 & 0,0011 & 0,0140 & 0,0151 & 0,0272 & 0,0259 \\
\hline faiz273 & 0,0000 & 0,1149 & 0,0085 & 0,0015 & 0,0165 & 0,0183 & 0,0348 & 0,0320 \\
\hline faiz365 & 0,0000 & 0,1303 & 0,0097 & 0,0018 & 0,0207 & 0,0215 & 0,0411 & 0,0371 \\
\hline faiz456 & 0,0000 & 0,1436 & 0,0113 & 0,0020 & 0,0236 & 0,0249 & 0,0476 & 0,0431 \\
\hline
\end{tabular}


Dalam studi ini kami menggunakan Generalized Pareto Distribution (GPD) untuk melakukan penilaian terhadap risiko suku bunga pada periode 2001 hingga 2009. Estimasi GPD terhadap data menghasilkan kecocokan antara model dan data untuk seluruh periode waktu dan lintas maturitas. Hasil estimasi menunjukkan bahwa tail indices memiliki bobot upper tail distribution yang semakin kecil, yang mengindikasikan bahwa ekor distribusi semakin lama akan semakin tipis dari satu periode ke periode lainnya (kecuali jatuh tempo pada faiz456 dan faiz456 periode kedua, serta faiz356 pada periode 3). Karakteristik ini menunjukkan bahwa risiko suku bunga cenderung mengalami penurunan.

Grafik 3 menunjukkan bahwa suku bunga memiliki tiga patahan structura/ dalam periode pertama. Meski demikian, karena alasan pertimbangan analisis ekonomi yang kuat, keseluruhan periode kami bagi ke dalam empat sub-siklus. Siklus-siklus ini sangatlah penting. Salah satu contoh adalah selama terjadinya resesi ekonomi, maka konsumen cenderung mengurangi konsumsi barang-barang mewah, sehingga banyak perusahaan pada barang konsumen tahan lama harus mempertimbangkan peningkatan risiko kredit mereka. Terlebih lagi, terdapat banyak bukti yang menunjukkan bahwa kondisi ekonomi makro juga sangat berpengaruh terhadap tingkat risiko. Sebagai contoh, saat krisis ekonomi terjadi, maka pertumbuhan ekonomi akan melambat atau bahkan bisa negatif, dan ini akan menghambat kecepatan penyesuaian modal. Dalam kondisi ini, pelaku ekonomi akan meminjam lebih sedikit; dan dengan demikian maka pertumbuhan PDB akan berhubungan positif dengan kecenderungan penerbitan surat hutang (lihat Hackbarth, Miao, dan Morellec, 2006).

Sejalan dengan pendapat di atas berdasarkan periode sampel kami, risiko tertinggi terjadi pada periode pertama sebagaimana tercermin dari nilai $\xi$ yang paling tinggi dibandingkan dengan tiga periode lainnya. Terkait dengan risiko, maka setelah periode pertama, tingkat risiko yang tinggi selanjutnya terjadi pada periode ketiga, namun hanya berlaku untuk pinjaman berjangka panjang yakni satu tahun atau lebih.

Pada periode kedua, yang dimulai dari 2003-07-10 dan berakhir pada 2006-06-01, parameter hasil estimasi $\xi$ memiliki nilai sebesar nol, kecuali pada jatuh tempo paling panjang (faiz456). Aturan ekonomi umum yang digunakan adalah semakin panjang periode jatuh tempo, maka semakin besar pula risiko yang akan timbul.

Periode 4 menunjukkan nilai $\xi$ nol untuk seluruh periode jatuh tempo, yang mengindikasikan bahwa periode ini berkaitan dengan periode risiko tingkat suku bunga yang paling rendah. Hasil ini nampaknya tidak sesuai dengan realitas karena periode inilah dampak krisis keuangan global pertama kali terasa bagi perekonomian Turki.

Pertanyaan yang muncul kemudian adalah mengapa krisis ekonomi memberikan dampak pada risiko yang berhubungan dengan ekonomi Turki? Interpretasinya dapat ditemukan pada implikasi makroekonomi dari sebuah krisis ekonomi. Selama terjadinya krisis global, tingkat harga dan tingkat suku bunga secara umum akan menurun. Penurunan harga disebabkan oleh penurunan permintaan barang, begitupun pada penurunan tingkat suku bunga. Dibandingkan 
periode sebelumnya, pada periode keempat, sensitifitas suku bunga terhadap investasi berkurang, dan ini mengimplikasikan terjadinya penurunan permintaan pinjaman.

Grafik 5 menunjukkan pengamatan mingguan terhadap total pinjaman konsumen dan klaim yang masih dalam proses hukum untuk selang periode antara 2004-06-25 dan 201001-01. Grafik tersebut dengan jelas menunjukkan bahwa permintaan pinjaman dari konsumen melambat pada periode terakhir, dan terdapat peningkatan dramatis untuk klaim yang masih dalam proses hukum. Ini memberikan kita kesimpulan bahwa penurunan risiko tingkat suku bunga pada periode ini lebih kecil dari yang diperkirakan.

Intepretasi ini telah teruji secara statistik sebagaimana disajikan pada Tabel 3. Uji statistik perubahan suku bunga untuk keempat periode tersebut mengindikasikan bahwa hasilnya signifikan. Kurtosis yang semakin besar meunjukkan bahwa variasi yang terjadi, dominan disebabkan oleh deviasi ekstrim yang bersifat sesekali, dan bukan akibat deviasi berukuran sedang yang bersifat sering (frequent modestly sized deviations).

\section{Tabel 3}

Joint Threshold Exceedances

periode 1: 2001-01-02 - 2003-10-06

\begin{tabular}{rr|rr} 
& & \multicolumn{2}{|c}{$Y$} \\
& & 1 & 0 \\
\hline \multirow{2}{*}{1} & 1 & 43 & 97 \\
& 0 & 97 & 455
\end{tabular}

odds ratio :

2,08

95\% confidence interval :

$[1,37,3,16]$

periode 2: 2003-10-07 - 2006-06-01

\begin{tabular}{rr|rr} 
& & \multicolumn{2}{|c}{$Y$} \\
\hline \multirow{2}{*}{} & 1 & 34 & 100 \\
& 0 & 100 & 432
\end{tabular}

odds ratio :

$95 \%$ confidence interval :

$[0,94,2,29]$

periode 3: 2006-06-02 - 2008-08-29

\begin{tabular}{|c|c|c|c|}
\hline & \multicolumn{2}{|c|}{$Y$} \\
\hline & & 1 & 0 \\
\hline \multirow[t]{2}{*}{$X$} & 1 & 31 & 83 \\
\hline & 0 & 83 & 372 \\
\hline
\end{tabular}

odds ratio :

95\% confidence interval :

$[1,04,2,69]$

periode 4: 2008-09-01 - 2009-12-31

\begin{tabular}{rr|rr} 
& & \multicolumn{2}{|c}{$Y$} \\
& & 1 & 0 \\
\hline$X$ & 1 & 18 & 48 \\
& 0 & 47 & 217
\end{tabular}

odds ratio :

95\% confidence interval :

$[0,93,3,22]$ 


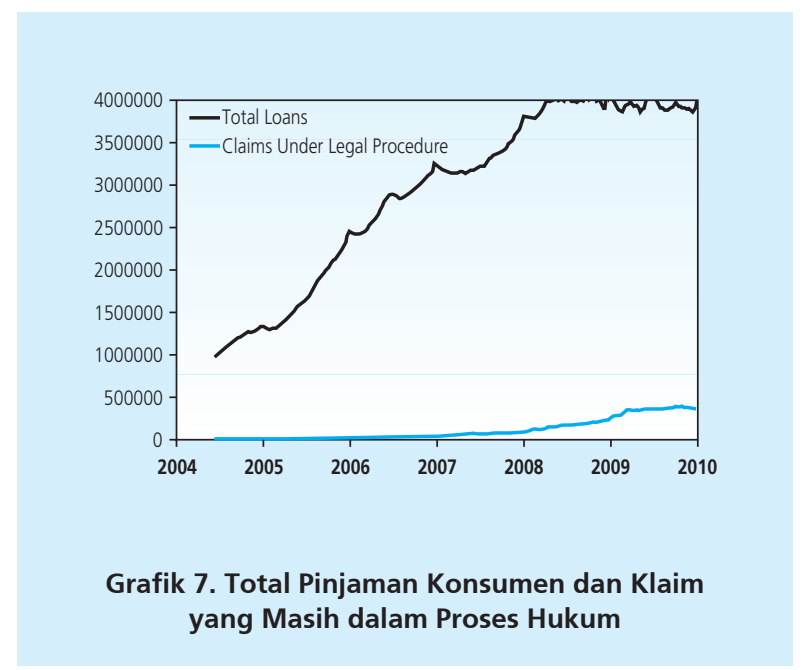

Temuan dalam paper ini juga sejalan dengan hubungan paritas suku bunga (covered interest parity). Tabel 3 menjelaskan joint threshold exceedances untuk keempat sub-periode yang diamati pada perekonomian Turki. Kami menggunakan nilai tukar dollar TL sebagai proksi pengukuran nilai tukar Turki. Perilaku simultan antara perubahan pada tingkat suku bunga Turki dan nilai tukar Lira terhadap USD sejalan dengan pendekatan yang kami lakukan terhadap penilaian suku bunga untuk menginvestigasi terjadinya joint daily threshold exceedances. Pada setiap periode, digunakan indikator untuk masing-masing variabel sebagai berikut:

$$
\begin{aligned}
& X t=\left\{\begin{array}{l}
1 \text { Jika USD-return exceedances terjadi pada hari ke } t \\
0 \text { Sebaliknya }
\end{array}\right. \\
& Y t=\left\{\begin{array}{l}
1 \text { Jika perubahan suku bunga return exceedances terjadi pada hari ke } t \\
0 \text { Sebaliknya }
\end{array}\right.
\end{aligned}
$$

Kami menyebutnya USD-return exceedance jika perubahan harga USD terhadap TL lebih besar dari 90\% kwantilnya atau lebih rendah dari 10\% kwantilnya, di mana kwantil bersifat spesifik untuk setiap periode. Lebih lanjut, interest rate change exceedance didefinisikan terjadi saat perubahan suku bunga lebih besar dari 90\% kwantilnya atau lebih rendah dari 10\% kwantilnya; kwantil ini juga bersifat period-specific. Tabel kontijensi untuk $X$ dan $Y$ termasuk rasio kecenderungannya disajikan pada Tabel 3. Rasio kecenderungan yang lebih besar dari 1 mengindikasikan hubungan positif antara $X$ dan $Y$, di mana diagonal utama dari tabel kontijensi memiliki frekuensi yang lebih tinggi dari yang diperkirakan berdasarkan hipotesis bahwa X dan Y bersifat independen.

Seperti yang diperkirakan, Tabel 3 menunjukkan bahwa hubungan positif terjadi pada seluruh periode, dan rasio kecenderungan mengindikasikan adanya hubungan yang sangat 
kuat pada periode 1. Secara statistik, hubungan positif yang signifikan (pada tingkat signifikansi $5 \%$ ) hanya terjadi pada periode 1 dan 3. Interest rate change exceedance akan berpengaruh terhadap perubahan suku bunga, dan hubungan ini sama untuk keempat periode. Hasil pengujian ini menggiring pada kesimpulan bahwa kondisi covered interest parity berlaku pada pasar keuangan Turki.

\section{KESIMPULAN}

Mengukur risiko suku bunga sangat penting untuk negara berkembang serta sistem keuangan global. Risiko di balik perilaku suku bunga tidak hanya memiliki dampak langsung terhadap pasar, namun mampu merubah struktur pasar. Paper ini secara jelas menunjukkan bahwa distribusi normal cenderung over-estimates dalam memperkirakan probabilitas terjadinya perubahan yang moderat dan justru under-estimates dalam memperkirakan probabilitas terjadinya perubahan yang besar. Hal ini tentunya tidak sesuai dengan analisis risiko pada kasus yang kami angkat.

Manfaat dari GPD pada konteks suku bunga dalam nilai absolut telah banyak digunakan pada berbagai literatur, dan pendekatan yang kami lakukan dalam paper ini berbeda karena kami menggunakan perubahan suku bunga mengingat bahwa risiko muncul lebih dikarenakan terjadinya perubahan yang tidak terduga pada suku bunga dan bukan pada nilai atau besaran suku bunga tersebut. Studi kami dengan jelas menunjukkan bahwa GPD, saat digunakan pada perubahan suku bunga, mampu meyajikan alat pengukuran risiko suku bunga yang lebih akurat, dan memungkinkan mengevaluasi risiko yang bersifat period-specific. 


\section{LAMPIRAN: STATISTIK PERUBAHAN SUKU BUNGA}

\begin{tabular}{|c|c|c|c|c|c|c|c|c|c|c|}
\hline \multicolumn{11}{|c|}{$\begin{array}{c}\text { Table } 4 \\
\text { Statistical Properties Perubahan Suku Bunga, Empat Periode }\end{array}$} \\
\hline & Faiz091 & Faiz182 & Faiz273 & Faiz365 & Faiz456 & Faiz091 & Faiz182 & Faiz273 & Faiz365 & Faiz456 \\
\hline \multicolumn{6}{|c|}{ Period 1 : 2001-01-02 - 2003-10-06 (692 obs.) } & \multicolumn{5}{|c|}{ Period 3 : 2006-06-02 - 2008-08-29 (569 obs.) } \\
\hline Mean & $-0,06$ & $-0,00$ & 0,07 & 0,14 & 0,20 & 0,05 & 0,04 & 0,04 & 0,04 & 0,03 \\
\hline std error & 0,16 & 0,23 & 0,27 & 0,28 & 0,33 & 0,03 & 0,04 & 0,04 & 0,05 & 0,06 \\
\hline Var & 21,04 & 30,36 & 47,56 & 66,06 & 83,40 & 0,71 & 0,80 & 1,03 & 1,35 & 1,70 \\
\hline std deviaton & 4,59 & 5,51 & 6,90 & 8,13 & 9,13 & 0,84 & 0,90 & 1,02 & 1,16 & 1,31 \\
\hline Skewness & 5,92 & 9,46 & 13,13 & 14,67 & 15,22 & 1,09 & 2,40 & 3,00 & 2,98 & 2,82 \\
\hline std error & 3,70 & $5 \mathrm{~m} 17$ & 6,66 & 7,32 & 7,76 & 0,87 & 1,36 & 1,28 & 1,22 & 1,13 \\
\hline Kurtosis & 102,35 & 184,97 & 283,47 & 322,95 & 334,71 & 10,96 & 24,74 & 30,26 & 29,05 & 26,44 \\
\hline std error & 39,15 & 67,89 & 118,18 & 127,24 & 139,63 & 5,33 & 11,98 & 13,83 & 11,51 & 11,83 \\
\hline \multicolumn{6}{|c|}{ Period 2 : 2003-10-07 - 2006-06-01 (666 obs.) } & \multicolumn{5}{|c|}{ Period 4 : 2008-09-01 - 2009-12-31 (332 obs.) } \\
\hline Mean & $-0,10$ & $-0,10$ & $-0,10$ & $-0,09$ & $-0,09$ & $-0,28$ & $-0,26$ & $-0,25$ & $-0,24$ & $-0,22$ \\
\hline std error & 0,04 & 0,04 & 0,04 & 0,06 & 0,05 & 0,06 & 0,07 & 0,08 & 0,09 & 0,09 \\
\hline Var & 0,73 & 0,91 & 1,29 & 1,76 & 2,24 & 1,16 & 1,45 & 1,89 & 2,43 & 3,03 \\
\hline std deviaton & 0,85 & 0,96 & 1,14 & 1,33 & 1,50 & 1,08 & 1,20 & 1,37 & 1,56 & 1,74 \\
\hline Skewness & $-1,62$ & $-0,52$ & 0,17 & 0,42 & 0,49 & $-0,52$ & $-0,38$ & $-0,24$ & $-0,17$ & $-0,11$ \\
\hline std error & 0,78 & 0,75 & 0,69 & 0,73 & 0,61 & 0,67 & 0,51 & 0,37 & 0,35 & 0,23 \\
\hline Kurtosis & 13,71 & 11,46 & 11,02 & 10,69 & 10,10 & 6,35 & 4,51 & 3,19 & 2,46 & 2,06 \\
\hline std error & 4,27 & 2,59 & 1,81 & 2,31 & 2,21 & 2,24 & 1,22 & 0,91 & 0,74 & 0,61 \\
\hline
\end{tabular}




\begin{tabular}{|c|c|c|c|c|c|}
\hline \multicolumn{6}{|c|}{$\begin{array}{c}\text { Tabel } 5 \\
\text { Kwantil perubahan tingkat suku bunga, empat periode }\end{array}$} \\
\hline & faiz091 & faiz182 & faiz273 & faiz365 & faiz456 \\
\hline \multicolumn{6}{|c|}{ period 1: 2001-01-02 - 2003-10-06 (692 observasi) } \\
\hline Min & 38.20 & 45.74 & 48.25 & 48.66 & 48.13 \\
\hline median & 0.10 & 0.13 & 0.16 & 0.14 & 0.13 \\
\hline Maks & 70.25 & 102.17 & 144.86 & 176.72 & 200.37 \\
\hline Hari min & $2001-02-26$ & $2001-02-26$ & $2001-02-26$ & $2001-02-26$ & $2001-02-26$ \\
\hline Hari maks & $2001-02-20$ & $2001-02-23$ & $2001-02-23$ & $2001-02-23$ & $2001-02-23$ \\
\hline \multicolumn{6}{|c|}{ period 2: 2003-10-07 - 2006-06-01 (666 observasi) } \\
\hline Min & 7.09 & 6.73 & 7.05 & 8.59 & 9.70 \\
\hline median & 0.00 & 0.02 & 0.07 & 0.07 & 0.13 \\
\hline Maks & 4.58 & 6.20 & 7.34 & 8.56 & 9.81 \\
\hline Hari min & 2004-09-08 & $2004-12-20$ & 2004-05-12 & 2004-05-12 & 2004-05-12 \\
\hline Hari maks & $2004-05-10$ & 2004-05-10 & 2004-05-10 & 2004-09-20 & $2004-09-20$ \\
\hline \multicolumn{6}{|c|}{ periode 3: 2006-06-02 - 2008-08-29 (569 observasi) } \\
\hline Min & 3.80 & 4.55 & 5.17 & 5.84 & 6.32 \\
\hline median & 0.00 & 0.00 & 0.00 & 0.00 & 0.05 \\
\hline Maks & 7.24 & 9.48 & 11.16 & 12.49 & 13.55 \\
\hline Hari min & 2006-07-04 & 2006-07-04 & 2006-07-04 & 2006-07-04 & 2006-07-04 \\
\hline Hari maks & 2006-06-26 & 2006-06-26 & $2006-06-26$ & 2006-06-26 & 2006-06-26 \\
\hline \multicolumn{6}{|c|}{ periode 4: 2008-09-01 - 2009-12-31 (332 observasi) } \\
\hline Min & 6.73 & 6.57 & 6.47 & 7.22 & 7.82 \\
\hline median & 0.22 & 0.21 & 0.19 & 0.17 & 0.13 \\
\hline Maks & 4.73 & 5.18 & 5.51 & 5.77 & 5.96 \\
\hline Hari min & 2009-01-16 & 2009-01-16 & 2009-01-16 & $2009-12-29$ & $2009-12-29$ \\
\hline Hari maks & $2008-10-27$ & $2008-10-27$ & $2008-10-27$ & $2008-10-27$ & $2008-10-27$ \\
\hline
\end{tabular}




\section{DAFTAR PUSTAKA}

Andolfatto, David. 2012. Liquidity Shocks, Real Interset Rates, and Global Imbalances, Federal Reserve Bank of St. Louis, Review, May/June 2012, 94(3), pp. 187-95.

Ang, A., and Bekaert, G. 2002. International asset allocation with regime shifts. The Review of Financial Studies 15, 1137-1187.

Bai, J., and Peron, P. 2003. Computation and analysis of multiple structural change models. Journal of Applied Econometrics 18, 1-22.

Bali, T.G., and Neftçi, S.N. 2001. Estimating the term structure of interest rate volatility in extreme values. Journal of Fixed Income, March 2001. Available at SSRN: http://ssrn.com/ abstract=262418.

Brigitte Desroches and Michael Francis. 2007. Global Savings, Investment, and World Real Interest Rates, Bank of Canada Review, winter, 2006-2007.

Carneiro, L.A. F., and Sherris, M. 2008. Corporate interest rate risk management with derivatives in Australia: Empirical results. Revista Contabilidade \& Financas 19, 86-107.

Coles, S. 2001. An Introduction to Statistical Modeling of Extreme Values. Springer, Berlin.

Dai, Q., and Singleton, K.J, 2002. Specification analysis of affine term structure models. Journal of Finance LV, 1943-1978.

Duffie, D., and Kan R, 1996. Yield factor model of interest rates. Mathematical Finance 6, 379-406.

Fisher, R.A. and Tippett, L.H.C. 1928. Limiting forms of the frequency distribution ofthe largest and smallest member of a sample, Proc. Camb. Phil. Soc. 24, 80-190.

Gençay, R., and Selçuk, F. 2006. Overnight borrowing, interest rates and extreme value theory. European Economic Review 50, 547-563.

Gençay, R., Selçuk, F., and UlugülyağCl, A. 2002. High volatility, thick tails and extreme value theory in value at risk estimation, Insurance: Mathematics and Economics 33, 337-356

Gençay, R., and Selçuk F. 2004. Extreme value theory and value at risk: Relative performance in emerging markets. Journal of Forecasting 20, 287-303. 
Hackbarth, D., and Miao, J., and Morellec, E. 2006. Capital structure, credit risk, and macroeconomic conditions. Journal of Financial Economics 82, 519- 550.

Hosking, J. R. M., and Wallis, J. R. (1987), "Parameter and Quantile Estimation for the Generalized Pareto Distribution," Technometrics, 29, 339-349.

Insel, A. 2003. The AKP and normalising democracy in Turkey. The South Atlantic Quarterly 102, 293-308.

Konstantin Borodin and Anton Strokov. 2011. Central bank Interest Rate and International Trade in BRIC Countries: Agriculture vs. Machinery Industry?, conference paper on "Will the „BRICs Decade continue?-Prospects for Trade and Growth”, Halle (Saale), Germany.

Meyfredi, J. 2005. Is There a Gain to Explicitly Modelling Extremes? Working Paper, Edhec Risk and Asset Management Research Centre Publications, Nice.

Mirko Abbritti, Salvatore Dell'Erba, Antonio Moreno, and Sergio Sola. 2013. Global Factors in the Term Structure of Interest Rates, International Monetary Fund, working paper, WP/13/223, November.

Paul Conway and Adrian Orr. 2002. The GIRM: A Global Interest Rate Model, occasional paper, Westpac Institutional Bank.

Philip Turner. 2014. The global long-term Interest Rate, Financial Risks and Policy Choices in EMEs, BIS Working Papers, No 441

Pickands, J. (1975), "Statistical Inference Using Extreme Order Statistics," The Annals of Statistics, 3, 119-131.

R Core Team 2013 R: A language and environment for statistical computing. R Foundation for Statistical Computing, Vienna, Austria. URL http://www.R-project.org/.

Schmidbauer, H., and Rösch, A. 2004. Joint threshold exceedances of stock index returns in bull and bear periods. Central European Journal of Operations Research 12, 197-209.

Stephenson, A.G. 2002. evd: Extreme Value Distributions. R News 2, 31-32.

Turanlı, M., and Ozden, H.U., and Demirhan, D. 2002. Seçim Tartışmalarının

Hisse Senedi Piyasalarına Etkisi, Istanbul Ticaret Universitesi Dergisi 2.

Woodford, M. 1999. Optimal Monetary Policy Inertia. NBER Working Papers 7261, Cambridge, Massachusetts.

Zeileis, A., and Kleiber, C., and Kramer W., and Hornik, K. 2003. Testing and dating of structural changes in practice. Computational Statistics and Data Analysis 44, 109-123. 
218 Buletin Ekonomi Moneter dan Perbankan, Januari 2014

Halaman ini sengaja dikosongkan 